\title{
Training in Neurology: Feedback from Graduates About the Psychiatry Component of Residency Training
}

Dorthea Juul, PhD, Laurie Gutmann, MD, Harold P. Adams, Jr., MD, Sarah A. O'Shea, MD, and Larry R. Faulkner, MD

Neurology ${ }^{\circledR}$ 2021;96:233-236. doi:10.1212/WNL.0000000000010857

\author{
Correspondence \\ Dr. Juul \\ djuul@abpn.com
}

\section{Abstract}

\section{Objective}

To obtain feedback from early career adult and pediatric neurologists about the psychiatry component of residency training.

\section{Methods}

A survey was developed and administered electronically to 4 cohorts of recently certified American Board of Psychiatry and Neurology diplomates.

\section{Results}

The response rate was $16 \%(431 / 2,677)$ and included 330 adult neurologists and 101 pediatric neurologists. Fewer than half of the respondents described themselves as extremely or quite satisfied with their psychiatry training whereas $26 \%$ of the adult neurologists and $33 \%$ of the pediatric neurologists felt slightly or not at all prepared for this component of practice. Four themes were identified in the respondents' suggestions for improving psychiatry training: provide more outpatient experience; provide more time/teaching in psychiatry; provide more experience with both pharmacologic and nonpharmacologic psychiatric treatments; and provide more exposure to patients with conditions likely to be encountered in neurology/child neurology practice.

\section{Conclusion}

These recent graduates of adult and pediatric neurology residency programs felt underprepared for the psychiatric issues they encountered in their patients. They suggested a number of strategies for better alignment of psychiatry training with the likely demands of practice. A model curriculum recently developed by the American Academy of Neurology's Consortium of Neurology Program Directors and the American Association of Directors of Psychiatric Residency Training also provides guidance for both neurology and psychiatry program directors. 


\section{Glossary}

AAN = American Academy of Neurology; ABPN = American Board of Psychiatry and Neurology.

In April 2015, the American Board of Psychiatry and Neurology (ABPN) organized a forum on residency competence requirements for educational leaders in neurology and psychiatry. Among the topics discussed at the forum was the contribution of psychiatric training to the professional development of adult and pediatric neurologists.

The current requirements for training in adult neurology include at least 1 month in clinical psychiatry. ${ }^{1}$ The Neurology Milestones address competence in psychiatry in the patient care category for adult neurologists. Level 4 competence, which is the graduation target, includes diagnosing common psychiatric disorders and initiating management of psychiatric comorbidities in patients with a neurologic disorder. ${ }^{2}$ The child neurology requirements include 1 month of training under the supervision of a child and adolescent psychiatrist. ${ }^{3}$ Similar to the Neurology Milestones, the Child Neurology Milestones define level 4 competence in cognitive, behavioral, and psychiatric disorders as diagnosis and management of patients with uncommon cognitive and behavioral disorders, diagnosis of patients with common psychiatric disorders, and management of complex combinations of medications with CNS effects. ${ }^{4}$

To enrich further deliberations about training requirements, the forum participants suggested surveying early career adult and pediatric neurologists about how well prepared they felt to manage patients with psychiatric disorders in their practices. Their feedback is described in this report.

\section{Methods}

A 22-item survey was developed based on issues discussed at the forum on residents' competency requirements and reviewed by the $8 \mathrm{ABPN}$ neurology directors. It included 8 demographic and practice-related items, 6 items addressing psychiatry training, and 8 items addressing primary care training (these results not reported here).

An anonymous online survey of 4 cohorts of recently certified ABPN diplomates (certified in 2010, 2011, 2013, or 2014) was conducted via the SurveyMonkey platform (surveymonkey.com) between April 29, 2016, and July 15, 2016. (The 2012 cohort was skipped to get a somewhat wider range of time in practice.) The survey link was distributed by direct invitation with a single-user link, and 2 follow-up e-mails were sent to nonrespondents. The diplomates were informed that the purpose of the survey was to obtain their insights and opinions about their residency training in primary care and in psychiatry and that the information would help the ABPN in its ongoing deliberations about training requirements in the ABPN's specialties.
Proportions were calculated for categorical variables. For the free response item, classifications were developed by one of the authors (D.J.) and reviewed and modified by a second author (H.P.A.). The 2 reviewers reached consensus on all of the responses.

This study was approved by the University of Iowa Institutional Review Board (201510761). Consent was obtained from all participants.

\section{Results}

The survey was administered to 2,677 adult and pediatric neurologists. The response rate was $16 \%(431 / 2,677)$ and included 330 adult neurologists and 101 pediatric neurologists. The margin of error for all respondents was $\pm 4 \%$ ( $95 \%$ confidence interval). The results were similar across the 4 cohorts; combined results are presented in the table.

\section{Practice Profile}

The majority of the respondents ( $91.5 \%$ of adult neurologists; $70.3 \%$ of pediatric neurologists) had done fellowship training. Almost all of the respondents ( $96.6 \%$ of adult neurologists; $98.0 \%$ of pediatric neurologists) worked in a setting that required a medical license, and the majority ( $87.3 \%$ of adult neurologists; $82.2 \%$ of pediatric neurologists) indicated that they spent most of their professional time in patient care. Over half $(53.3 \%$ of adult neurologists; $65.3 \%$ of pediatric neurologists) reported that their principal practice setting was an academic institution, followed by private practice/private institution (36.4\% of adult neurologists; $25.7 \%$ of pediatric neurologists).

\section{Psychiatry Training in Residency}

Of the adult neurologists, $58.2 \%$ reported having experience on a psychiatry consultation service, $49.4 \%$ on a psychiatry inpatient unit, and $20.0 \%$ on a psychiatry outpatient unit. Of the pediatric neurologists, $53.5 \%$ had experience on a psychiatry outpatient unit, $48.5 \%$ on a psychiatry inpatient unit, and $41.6 \%$ on a psychiatry consultation service.

The respondents were asked about their overall satisfaction with their psychiatry training during residency and how well prepared they felt for the psychiatric aspects of practice. Of the adult neurologists, $47.2 \%$ were extremely or quite satisfied with their psychiatry training, $30.2 \%$ were moderately satisfied, and $22.5 \%$ were slightly or not at all satisfied. Of the pediatric neurologists, $35.0 \%$ were extremely or quite satisfied with their psychiatry training, $34.0 \%$ were moderately satisfied, and $31.0 \%$ were slightly or not at all satisfied. 
Table Psychiatry Training Survey Results

\begin{tabular}{|c|c|c|}
\hline Respondents' characteristics & $\begin{array}{l}\text { Adult } \\
\text { neurologists, } \% \\
(n)(\text { total } n=330)\end{array}$ & $\begin{array}{l}\text { Pediatric } \\
\text { neurologists, \% } \\
(n)(\text { total } n=101)\end{array}$ \\
\hline Fellowship training & $91.5(302)$ & $70.3(71)$ \\
\hline $\begin{array}{l}\text { Working in a position that } \\
\text { requires a medical license }\end{array}$ & $96.6(319)$ & $98.0(99)$ \\
\hline \multicolumn{3}{|l|}{ Principal practice area } \\
\hline Patient care & $87.3(288)$ & $82.2(83)$ \\
\hline Research & $9.4(31)$ & $12.9(13)$ \\
\hline Other & $3.3(11)$ & $5.0(5)$ \\
\hline \multicolumn{3}{|l|}{ Principal practice setting } \\
\hline Academic institution & $53.3(176)$ & $65.3(66)$ \\
\hline $\begin{array}{l}\text { Private practice/private } \\
\text { institution }\end{array}$ & $36.4(120)$ & $25.7(26)$ \\
\hline Other & $10.3(34)$ & $18.8(19)$ \\
\hline \multicolumn{3}{|l|}{$\begin{array}{l}\text { Psychiatry training sites in } \\
\text { residency }\end{array}$} \\
\hline Psychiatry inpatient unit & $49.4(163)$ & $48.5(49)$ \\
\hline Psychiatry outpatient unit & $20.0(66)$ & $53.5(54)$ \\
\hline $\begin{array}{l}\text { Psychiatry consultation } \\
\text { service }\end{array}$ & $58.2(192)$ & $41.6(42)$ \\
\hline $\begin{array}{l}\text { Respondents' opinions } \\
\text { about psychiatry training }\end{array}$ & $n=324$ & $\mathrm{n}=100$ \\
\hline \multicolumn{3}{|l|}{$\begin{array}{l}\text { Overall, how satisfied were } \\
\text { you with the psychiatry } \\
\text { training you had during } \\
\text { residency? }\end{array}$} \\
\hline Extremely satisfied & $13.6(44)$ & $6.0(6)$ \\
\hline Quite satisfied & $33.6(109)$ & $29.0(29)$ \\
\hline Moderately satisfied & $30.2(98)$ & $34.0(34)$ \\
\hline Slightly satisfied & $17.3(56)$ & $22.0(22)$ \\
\hline Not at all satisfied & $5.2(17)$ & $9.0(9)$ \\
\hline \multicolumn{3}{|l|}{$\begin{array}{l}\text { Overall, how well did your } \\
\text { psychiatry training during } \\
\text { residency prepare you for } \\
\text { your current practice? }\end{array}$} \\
\hline Extremely well & $9.3(30)$ & $6.0(6)$ \\
\hline Quite well & $27.8(90)$ & $23.0(23)$ \\
\hline Moderately well & $37.0(120)$ & $38.0(38)$ \\
\hline Slightly well & $18.2(59)$ & $24.0(24)$ \\
\hline Not at all well & $7.7(25)$ & $9.0(9)$ \\
\hline
\end{tabular}

In terms of preparation for this aspect of practice, $37.0 \%$ of the adult neurologists felt quite or extremely well prepared, $37.0 \%$ felt moderately well prepared, and $25.9 \%$ felt slightly or not at all prepared. Of the pediatric neurologists, $29.0 \%$ felt quite or extremely well prepared, $38.0 \%$ felt moderately well prepared, and $33.0 \%$ felt slightly or not at all prepared.
The respondents were asked for suggestions to improve psychiatry training, and 184 (42.7\%) of them provided 226 suggestions. A content analysis yielded 4 themes. The most common suggestion (98/226 [43.4\%]) was for more outpatient experience. A neurologist wrote, "Would have appreciated some outpatient psychiatry exposure rather than just consult service, since as a primarily outpatient neurologist I manage so many psychiatric medications chronically for my patients." A pediatric neurologist commented, "Child psychiatry outpatient clinic visits: to understand less acute/more chronic psychiatric concerns." With regard to this issue, only $20.0 \%$ of the adult neurologists and $53.5 \%$ of the pediatric neurologists reported having experience in an outpatient setting.

The second most common theme was more time/teaching in psychiatry (61/226 [27.0\%]). A pediatric neurologist wrote, "I had minimal exposure to psychiatry, and it would have been great to have more training since dealing with families and kids with neurologic disorders carries a lot of psychiatry comorbidity." A neurologist wrote, "It would be helpful to have a structured evidence-based lecture series on the topics that are most relevant to neurologists."

The third most common theme was more exposure to both pharmacologic and nonpharmacologic psychiatric treatments (39/226 [17.3\%]). While managing psychiatric medications was mentioned more frequently, suggestions for training in other modalities (e.g., psychotherapy, cognitive behavioral therapy, neuropsychiatric testing, electroconvulsive therapy) were also made. An adult neurologist wrote, "Ensure that outpatient psychiatric management of common comorbid psychiatric disorders is incorporated into the training." A pediatric neurologist stated that it would have been more helpful to learn "how to deal with the $\mathrm{ADHD}$, behavior problems that we are asked to manage now."

The fourth theme was greater exposure to patients likely to be encountered in neurology/child neurology practice (28/226 [12.4\%]). An adult neurologist wrote, "Focus on common psych issues seen in neuro patients." A pediatric neurologist stated, "I would have benefited enormously if I had learned more about addressing psychiatric diseases in atypical/ developmentally delayed children, which are the bulk of what I see." Some of the specific conditions mentioned by the adult neurologists as particularly relevant to practice were depression, anxiety, and conversion disorders. In addition to these, the pediatric neurologists also cited attention-deficit/ hyperactivity disorder, autism, and behavior problems.

Limitations of the survey are that it only included ABPN certified neurologists, and the response rate was relatively low (16\%) compared to, for example, that for a recent resident survey (24\%) conducted by the American Academy of Neurology (AAN). ${ }^{5}$ Compared to the respondents in an AAN member survey, more of these neurologists indicated that their practice setting was academic (university-based) (57\% vs $28 \%) .{ }^{6}$ However, they were similar in that the majority reported 
spending $76 \%-100 \%$ of their time in direct patient care, and the mean percent of time spent in clinical practice in the AAN survey was $72.8 .{ }^{6}$ For adult neurologists, the percent completing subspecialty training (92\%) was similar to the percent planning to pursue it (93\%) for adult neurology residents reported by Jordan et al. ${ }^{5}$ For pediatric neurologists, the percent with subspecialty training $(70 \%)$ was somewhat higher than that in the Jordan et al. ${ }^{5}$ resident survey (56\%). Taken together, these similarities suggest that the results are reasonably generalizable for recent adult and pediatric neurology graduates.

Overall, fewer than half of recently board-certified adult and pediatric neurologists were extremely or quite satisfied with their psychiatry training and fewer than half felt extremely or well prepared for the psychiatric aspects of neurology/child neurology practice. Periodic surveys of neurology residents have indicated that they generally had favorable impressions of their residency programs. ${ }^{5,7,8}$ None of those surveys specifically addressed the psychiatry aspects of training, nor had the respondents already entered practice. Hence, this study expands our understanding of an additional component of residency training. Further highlighting the need for adequate training was the observation made by a number of respondents about the difficulty of obtaining psychiatric care for their patients because of the shortage of psychiatrists.

The most common suggestions for improving psychiatry training were to provide more time in psychiatry with more outpatient exposure where residents are more likely to encounter patients with conditions relevant to neurology/child neurology and more exposure to psychiatry treatments, both pharmacologic and nonpharmacologic. Some specific strategies to consider are developing extended outpatient experiences, e.g., a half day clinic/week for 6 months or more; creating collaborative clinics that combine neurology and psychiatry (psychiatrists have expressed a need for enhanced neurology training ${ }^{9}$ ); and neurology program directors working more closely with psychiatry to ensure that their residents are placed in more appropriate rotations. Recently, the AAN's Consortium of Neurology Program Directors and the American Association of Directors of Psychiatric Residency Training developed a model curriculum for the psychiatry component of adult neurology training ${ }^{10}$ that provides guidance for both neurology and psychiatry program directors.

Writing in 2008, Aminoff, a leading neurology educator, stated, "If the neurologists of tomorrow are to have the clinical skills that they require, they need to have adequate training in general internal medicine and psychiatry: neurology alone is not enough." $11, \mathrm{p} 1915$ More recently, Perez et al. ${ }^{12}$ and Keshavan et al. ${ }^{13}$ argued for more training in psychiatry for neurologists (and more neurology training for psychiatrists) as advances in basic and clinical neuroscience have "blurred the boundaries between the 2 disciplines." ${ }^{3, \mathrm{pE} 1}$ The survey results reported here provide support for these positions and strategies for accomplishing them.

\section{Disclosure}

The authors report no disclosures relevant to the manuscript. Go to Neurology.org/N for full disclosures.

\section{Study Funding}

No targeted funding reported.

Appendix Authors

\begin{tabular}{lll}
\hline Name & Location & Contribution \\
\hline $\begin{array}{l}\text { Dorthea } \\
\text { Juul, PhD }\end{array}$ & $\begin{array}{l}\text { American Board of } \\
\text { Psychiatry and }\end{array}$ & $\begin{array}{l}\text { Designed and conceptualized } \\
\text { study, analyzed the data, } \\
\text { Neurology, Inc., Deerfield, } \\
\text { IL }\end{array}$ \\
& $\begin{array}{l}\text { drafted and revised the } \\
\text { manuscript for intellectual } \\
\text { content }\end{array}$
\end{tabular}

\begin{tabular}{lll}
\hline Laurie & University of lowa Carver & Interpreted the data, revised \\
Gutmann, & College of Medicine, lowa & $\begin{array}{l}\text { the manuscript for intellectual } \\
\text { content }\end{array}$ \\
MD & City &
\end{tabular}

Harold P. University of lowa Carver Interpreted the data, revised

Adams, Jr., College of Medicine, lowa the manuscript for intellectual MD City content

\begin{tabular}{lll}
\hline Sarah A. & Boston University School & $\begin{array}{l}\text { Designed and conceptualized } \\
\text { study, interpreted the data, } \\
\text { O'Shea, }\end{array}$ \\
MD & & $\begin{array}{l}\text { revised the manuscript for } \\
\text { intellectual content }\end{array}$
\end{tabular}

\begin{tabular}{lll}
\hline $\begin{array}{l}\text { Larry R. } \\
\text { Faulkner, }\end{array}$ & $\begin{array}{l}\text { American Board of } \\
\text { Psychiatry and }\end{array}$ & $\begin{array}{l}\text { Designed and conceptualized } \\
\text { study, interpreted the data, }\end{array}$ \\
MD & IL & $\begin{array}{l}\text { Nevised the manuscript for } \\
\text { revisel, Incerfield, } \\
\text { intellectual content }\end{array}$ \\
\hline
\end{tabular}

\section{References}

1. Accreditation Council for Graduate Medical Education. ACGME Program Requirements for Graduate Medical Education in Neurology. Available at: acgme.org/Portals/0/PFAssets/ProgramRequirements/180_Neurology_2019.pdf?ver=2019-0618-132333-227. Accessed August 14, 2019.

2. Accreditation Council for Graduate Medical Education and American Board of Psychiatry and Neurology. The Neurology Milestone Project. Available at: acgme. org/Portals/0/PDFs/Milestones/NeurologyMilestones.pdf?ver=2015-11-06120526-253. Accessed August 14, 2019.

3. Accreditation Council for Graduate Medical Education. ACGME Program Require ments for Graduate Medical Education in Child Neurology. Available at: acgme.org/ Portals/0/PFAssets/ProgramRequirements/185_ChildNeurology_2019.pdf? ver=2019-06-18-133226-337. Accessed August 14, 2019.

4. Accreditation Council for Graduate Medical Education and American Board of Psychiatry and Neurology. The Child Neurology Milestone Project. Available at: acgme.org/Portals/0/PDFs/Milestones/ChildNeurologyMilestones.pdf?ver=201511-06-120533-693. Accessed August 14, 2019.

5. Jordan JT, Mayans D, Schneider L, Adams N, Khawaja AM, Engstrom J. Education research: neurology resident education: trending skills, confidence, and professional preparation. Neurology 2016;86:e112-e117.

6. Member Research Subcommittee of the American Academy of Neurology. 2015 Insights Report: Based on 2014 Data and Information. Minneapolis: American Academy of Neurology; 2015.

7. Johnson NE, Maas MB, Coleman M, Józefowicz R, Engstrom J. Education research: neurology training reassessed: the 2011 American Academy of Neurology resident survey results. Neurology 2012;79:1831-1834.

8. Freeman WD, Nolte CM, Matthews BR, Coleman M, Corboy JR. Results of the American Academy of Neurology resident survey. Neurology 2011;76:e61-e67.

9. Juul D, Lyness JM, Thomas CR, Faulkner LR. Primary care and neurology in psychiatry residency training: a survey of early career psychiatrists. Acad Psychiatry 2019; 43:51-55.

10. Psychiatry curriculum for neurology residents. Available at: www.aan.com/siteassets/ home-page/tools-and-resources/academic-neurologist-researchers/program-andfellowship-directors/aan-psychiatry-curriculum-for-neurology-residents_created-december-2019.pdf. Accessed May 20, 2020

11. Aminoff MJ. Training in neurology. Neurology 2008;70:1912-1915.

12. Perez DL, Keshavan MS, Schartf JM, Boes AD, Price BH. What can neurology learn from psychiatry? J Neuropsychiatry Clin Neurosci 2018;30:271-278.

13. Keshavan MS, Price BH, Martin JB. The convergence of neurology and psychiatry: the importance of cross-disciplinary education. JAMA 2020;324:554-555. 


\section{Neurology}

\section{Training in Neurology: Feedback from Graduates About the Psychiatry Component of Residency Training \\ Dorthea Juul, Laurie Gutmann, Harold P. Adams, Jr, et al.}

Neurology 2021;96;233-236 Published Online before print September 10, 2020

DOI 10.1212/WNL.0000000000010857

This information is current as of September 10, 2020

\section{Updated Information \&} Services

References

Subspecialty Collections

Permissions \& Licensing

Reprints including high resolution figures, can be found at: http://n.neurology.org/content/96/5/233.full

This article cites 7 articles, 4 of which you can access for free at: http://n.neurology.org/content/96/5/233.full\#ref-list-1

This article, along with others on similar topics, appears in the following collection(s):

All Education

http://n.neurology.org/cgi/collection/all_education

Other Education

http://n.neurology.org/cgi/collection/other_education

Information about reproducing this article in parts (figures,tables) or in its entirety can be found online at:

http://www.neurology.org/about/about_the_journal\#permissions

Information about ordering reprints can be found online:

http://n.neurology.org/subscribers/advertise

Neurology ${ }^{\circledR}$ is the official journal of the American Academy of Neurology. Published continuously since 1951, it is now a weekly with 48 issues per year. Copyright @ 2020 American Academy of Neurology. All rights reserved. Print ISSN: 0028-3878. Online ISSN: 1526-632X.

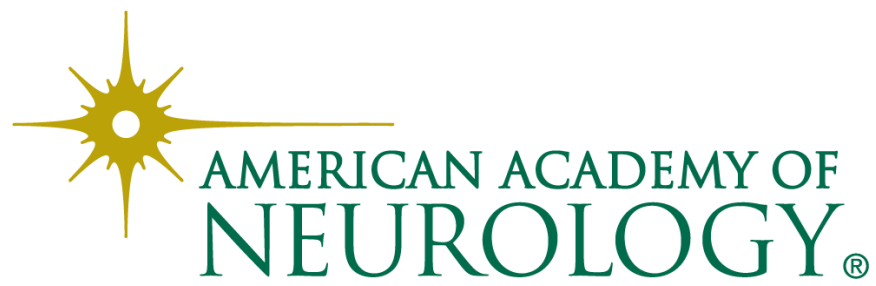

